\title{
PELATIHAN KOMPETENSI AIR CONDITIONING (AC) BAGI GURU SMK BIDANG KETEKNIKAN KOTA BALIKPAPAN
}

\author{
Syaeful Akbar ${ }^{1}$, Wahyu Anhar ${ }^{2}$, Basri Dahlan ${ }^{3}$ \\ ${ }^{1,2,3}$ Jurusan Teknik Mesin, Politeknik Negeri Balikpapan \\ Jalan Soekarno-Hatta, KM.8 Balikpapan 76126 \\ Email: ${ }^{2}$ wahyu.anhar@poltekba.ac.id
}

\begin{abstract}
Abstrak
Kalimantan Timur, khususnya Balikpapan merupakan sektor energi sehingga banyak terdapat industri perminyakan, gas, dan pertambangan, termasuk industri pendukung seperti alat berat, dan otomotif (light vehicle). Sinkronisasi elemen kompetensi SMK terhadap stakeholders/industri adalah mutlak harus dikuasai siswa/siswi SMK. Salah satu kompetensi dalam bidang alat berat, dan otomotif adalah kompetensi air conditioning (AC). Penguasaan kompetensi AC menjadi penting demi menunjang perangkat kerja alat berat, dan otomotif. Minimnya kompetensi guru dan alat praktek AC di sekolah menjadi latar belakang dilakukannya kegiatan pelatihan kompetensi AC bagi para guru SMK bidang keteknikan. Tujuan kegiatan pelatihan adalah peningkatan kompetensi AC bagi pada guru, dan mampu membuat alat praktek AC secara mandiri. Materi teori meliputi konsep AC, sistem kerja, perhitungan dan desain $\mathrm{AC}$, dan refrigerant. Kegiatan praktek menitikberatkan pada perancangan, perakitan, dan pembuatan alat praktek AC. Penilaian keberhasilan pelatihan dilakukan menggunakan perangkat kuesioner yang dibagikan kepada peserta pelatihan. Variabel penilaian meliputi efisiensi waktu, kualitas materi, kualitas narasumber, sarana prasarana teori/praktek, dan pelayanan panitia. Berdasarkan hasil penilaian bahwa pelatihan telah diselenggarakan dengan baik. Diakhir kegiatan pelatihan, dilakukan penyerahan alat praktek AC yang digunakan dalam kegiatan pelatihan kepada salah satu SMK peserta pelatihan.
\end{abstract}

Kata Kunci: pelatihan, air conditioning, guru SMK

\section{Abstract}

East Kalimantan, especially Balikpapan is an energy sector. There are many oil, gas and mining industries, including supporting industries such as heavy equipment and light vehicles. Synchronization of SMK competency elements to stakeholders/industry is absolutely must be mastered by SMK students. One of the competencies in heavy equipment and automotive is air conditioning (AC) competency. Mastery of AC competencies becomes important for supporting heavy equipment and automotive work tools. The lack of teacher competency, and AC practice tools in schools are the reason of implementation AC competency training especially for vocational engineering teachers. The purpose of the training activities is to improve AC competencies for teachers, and be able to make $A C$ practice tools independently. Theoretical material includes the concept of air conditioning, work systems, calculation and design of air conditioners, and refrigerants. Practical activities focus on the design, assembly, and manufacture of AC practice equipment. The assessment of the success of the training was carried out using by questionnaire that was distributed to the trainees. Assessment variables include time efficiency, material quality, 
resource quality, theoretical/practical infrastructure, and committee services. Based on the results of the assessment that the training has been held properly. At the end of the training activity, an AC practice tool was handed over which was used in the training activities to one of the vocational training participants.

Keywords: training; air conditioning; vocational teachers

\section{Latar Belakang Masalah}

Artikel ini disusun berdasarkan Kegiatan Pengabdian Kepada Masyarakat (PKM) Politeknik Negeri Balikpapan (Poltekba) Tahun 2019. Kegiatan yang dilakukan adalah pelatihan kompetensi mengenai AC bagi guru SMK bidang keteknikan di Kota Balikpapan. Pelatihan yang dilaksanakan terbagi menjadi 2 topik pelatihan, yang terdiri dari pelatihan pembuatan alat praktek AC, dan pelatihan kompetensi AC.

Kalimantan Timur secara umum, dan Balikpapan secara khusus merupakan sektor/koridor energi (minyak, gas, dan tambang), maka banyak terdapat industri perminyakan, gas, dan pertambangan, termasuk industri pendukungnya seperti alat berat, dan otomotif (light vehicle). Sinkronisasi elemen kompetensi SMK terhadap stakeholders/industri adalah mutlak harus dikuasai siswa-siswi SMK. Salah satu kompetensi dalam bidang alat berat, dan otomotif adalah kompetensi AC. Penguasaan kompetensi AC menjadi penting demi menunjang perangkat kerja alat berat, dan otomotif. Perangkat dan teknologi AC yang digunakan baik untuk otomotif, bangunan, dan penerapan lainnya telah sangat berkembang. Penggunaan microcontroller pada perangkat AC dapat berfungsi sebagai sensor temperatur sehingga tidak diperlukan lagi pengaturan temperatur kerja AC (pengaturan temperatur otomatis) [1]. Proses kerja AC juga telah dikembangkan tidak hanya satu kali siklus tetapi menjadi dua kali siklus secara parallel [2]. Pemanfaatan panas dari sinar matahari dan natural cooling juga telah dikembangkan dalam perangkat AC yang dikenal dengan solar absorptionsubcooled compression hybrid cooling system (SASCHCS) [3].

Minimnya jumlah guru yang memiliki kompetensi AC, dan alat praktek AC maka perlu dilakukan kegiatan pelatihan kompetensi AC bagi para guru melalui kegiatan PKM Poltekba tahun 2019. Tujuan yang ingin dicapai adalah peningkatan kompetensi AC bagi pada guru, dan mampu membuat alat praktek AC secara mandiri.

\section{Masalah}

Tabel 1. Data sekolah terkait pembelajaran kompetensi AC

\begin{tabular}{|c|c|c|c|c|c|c|c|c|}
\hline No & Uraian & $\bar{Z}$ & $\sum_{n}^{n}$ & $\sum_{\infty}^{\infty}$ & 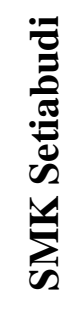 & 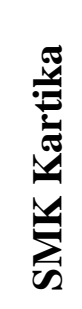 & 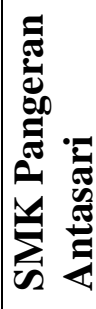 & 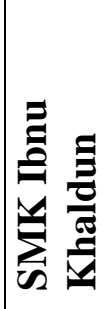 \\
\hline 1. & Jumlah siswa otomotif & 285 & 57 & 51 & 210 & 128 & 468 & 30 \\
\hline 2. & Jumlah siswa alat berat & 54 & 0 & 0 & 150 & 160 & 0 & 0 \\
\hline 3. & Jumlah guru otomotif & 13 & 6 & 7 & 5 & 9 & 8 & 3 \\
\hline 4. & Jumlah guru alat berat & 3 & 0 & 0 & 5 & 7 & 0 & 0 \\
\hline 5. & $\begin{array}{l}\text { Jumlah guru dengan } \\
\text { sertifikat kompetensi AC }\end{array}$ & 1 & 0 & 0 & 0 & 0 & 0 & 0 \\
\hline 6. & Jumlah alat praktek AC & 1 & 1 & 0 & 1 & 0 & 0 & 0 \\
\hline
\end{tabular}


Kota Balikpapan memiliki 7 SMK bidang keteknikan, yang terdiri 3 sekolah kejuruan negeri, dan 4 sekolah kejuruan swasta. Berdasarkan hasil kegiatan observasi ke sekolahsekolah SMK keteknikan di Kota Balikpapan didapatkan data mengenai kondisi pembelajaran kompetensi AC. Tabel 1. menunjukkan data kondisi pembelajaran kompetensi AC.

Berdasarkan Tabel 1 tersebut diketahui bahwa jumlah alat praktek AC di tiap SMK bidang keteknikan sangat minim jika berbanding dengan jumlah siswa. Bahkan di beberapa sekolah, ada yang tidak memiliki alat praktek AC. Guru dengan sertifikat kompetensi AC sangat sedikit, hanya satu sekolah yaitu SMKN 1 Balikpapan yang memiliki sertifikat kompetensi AC bagi gurunya. Oleh karena itu, Poltekba melalui kegiatan pengabdian tahun 2019 mengadakan pelatihan berkaitan dengan kompetensi AC bagi guru SMK bidang keteknikan di Kota Balikpapan.

\section{Metode}

Proses kerja dalam kegiatan PKM ini seperti ditunjukkan dalam Gambar 1. Kegiatan diawali dengan observasi ke sekolah-sekolah SMK bidang keteknikan. Berdasarkan diskusi bersama dengan pihak sekolah maka perlu dilaksanakan pelatihan kompetensi AC bagi para guru SMK. Dalam rangka lancarnya kegiatan pelatihan AC bagi para guru SMK maka dilakukan beberapa persiapan yang terdiri dari persiapam alat praktek AC, modul pelatihan, dan tempat pelaksanaan.

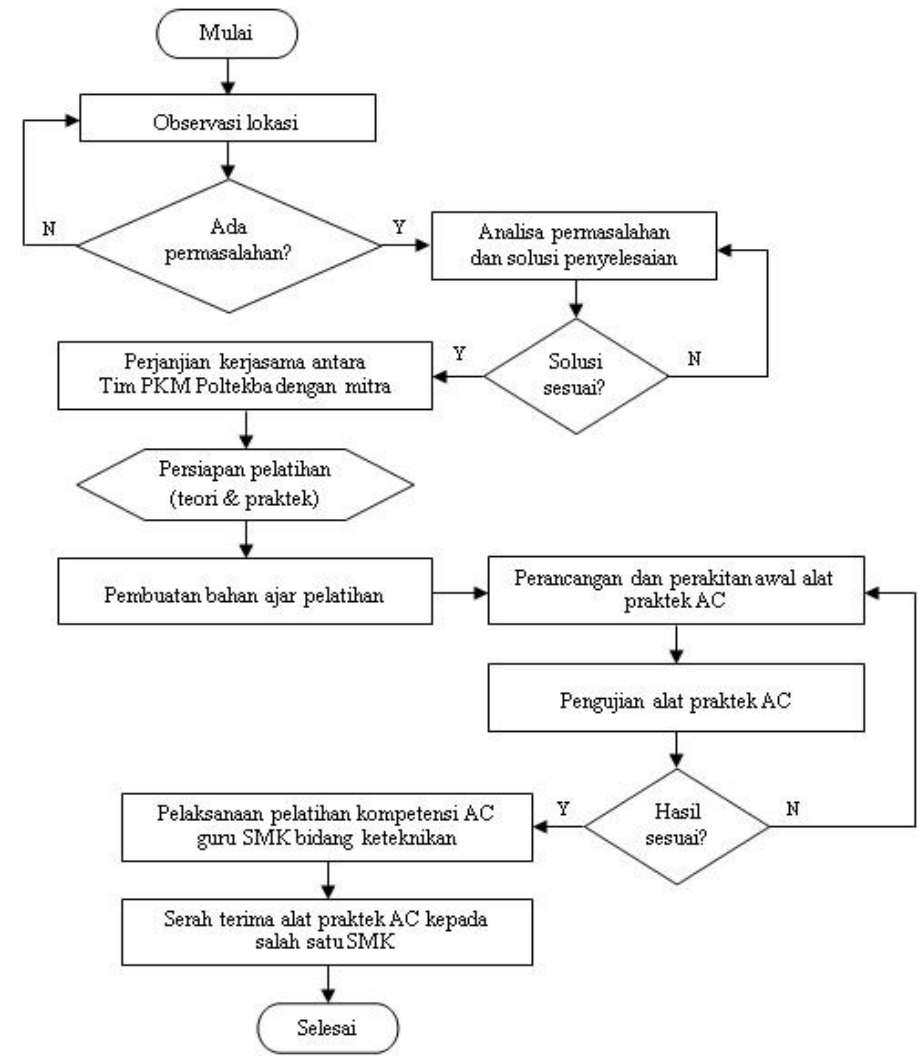

Gambar 1. Alur kegiatan

Kegiatan perancangan dan pembuatan alat praktek AC dilakukan di Workshop Jurusan Teknik Mesin Poltekba. Gambar 2 menunjukkan proses pembuatan dan perakitan alat praktek AC. Alat praktek yang telah selesai selanjutnya beberapa dilakukan pengujian antara lain kebocoran rangkaian, daya kerja komponen, dan proses pendinginan. Setelah dilakukan 
pengujian dan alat praktek AC bekerja dengan baik, maka komponen-komponen AC kembali dilepas untuk dirakit kembali pada kegiatan pelatihan (praktek).

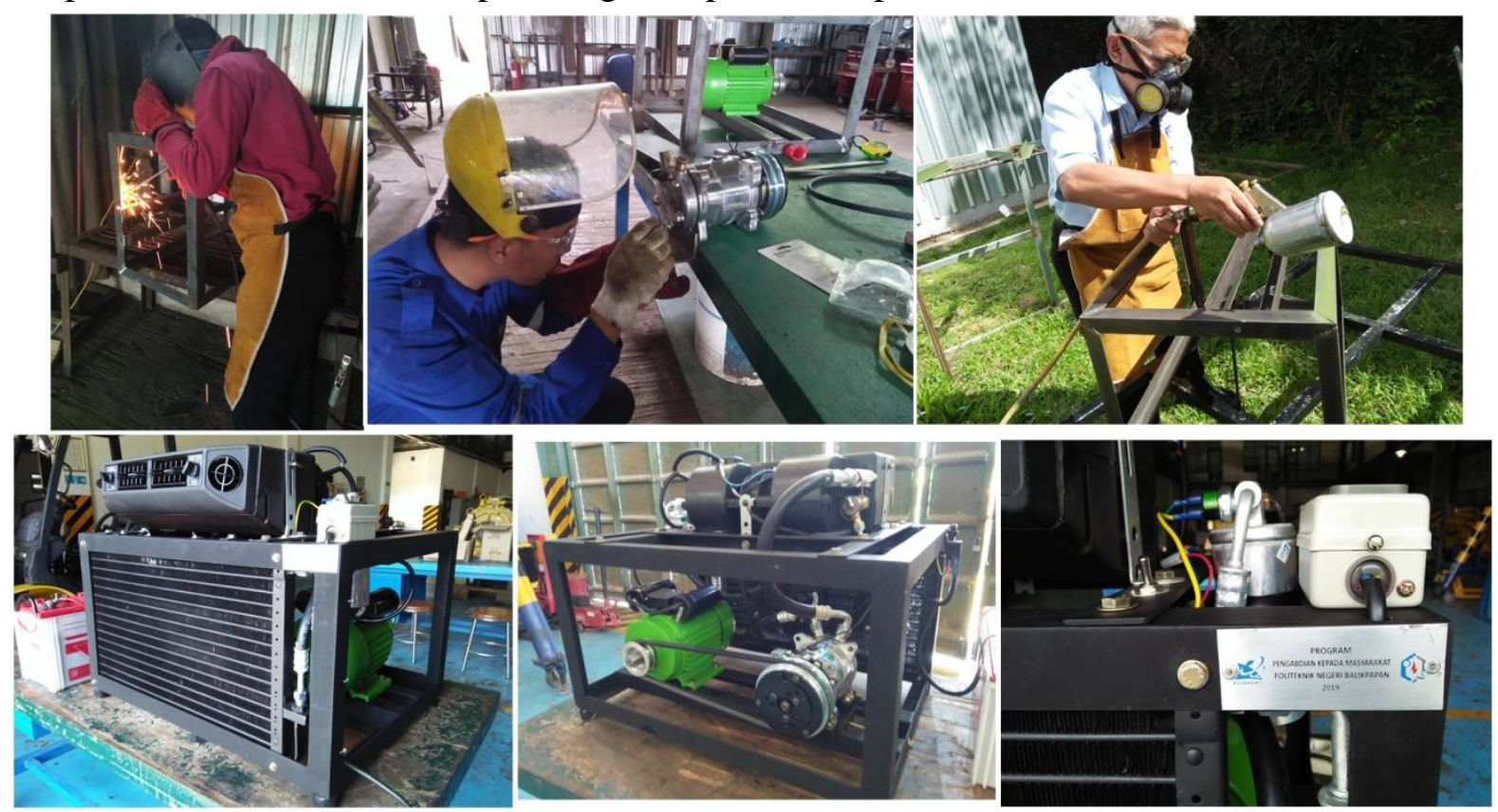

Gambar 2. Pembuatan dan perakitan alat praktek AC

Kegiatan pelatihan terbagi menjadi 2 bagian, yaitu teori mengenai AC dan praktek terkait alat praktek AC. Pelatihan dilaksanakan selama 2 hari, dengan durasi pelatihan teori dan praktek masing-masing selama 1 hari. Metode yang digunakan dalam teori adalah metode ceramah, diskusi, dan demonstrasi. Kegiatan demonstrasi dilakukan untuk menambah pemahaman pengetahuan dan cara kerja AC. Kegiatan praktek diberikan kepada peserta pelatihan untuk meningkatkan keterampilan merancang, merakit, dan membuat alat praktek AC. Peserta selama kegiatan teori dan praktek mendapatkan modul AC, flash disk yang berisikan tentang materi pengetahuan dan keterampilan terkait kompetensi $\mathrm{AC}$, dan job sheet praktek.

Untuk memudahkan keikutsertaan peserta dalam pelatihan maka waktu pelaksanaan ditentukan berdasarkan kesepakatan dengan pihak sekolah. Selain itu, demi kelancaran kegiatan maka Poltekba membuat surat undangan terkait penyelenggaran pelatihan bagi para guru SMK. Akhir kegiatan pelatihan akan diserahkan alat praktek AC kepada salah satu sekolah SMK yang telah ditentukan oleh Poltekba melalui beberapa kriteria. Penyerahan alat praktek AC dituangkan dalam Berita Serah Terima Alat. 


\section{Hasil dan Pembahasan}

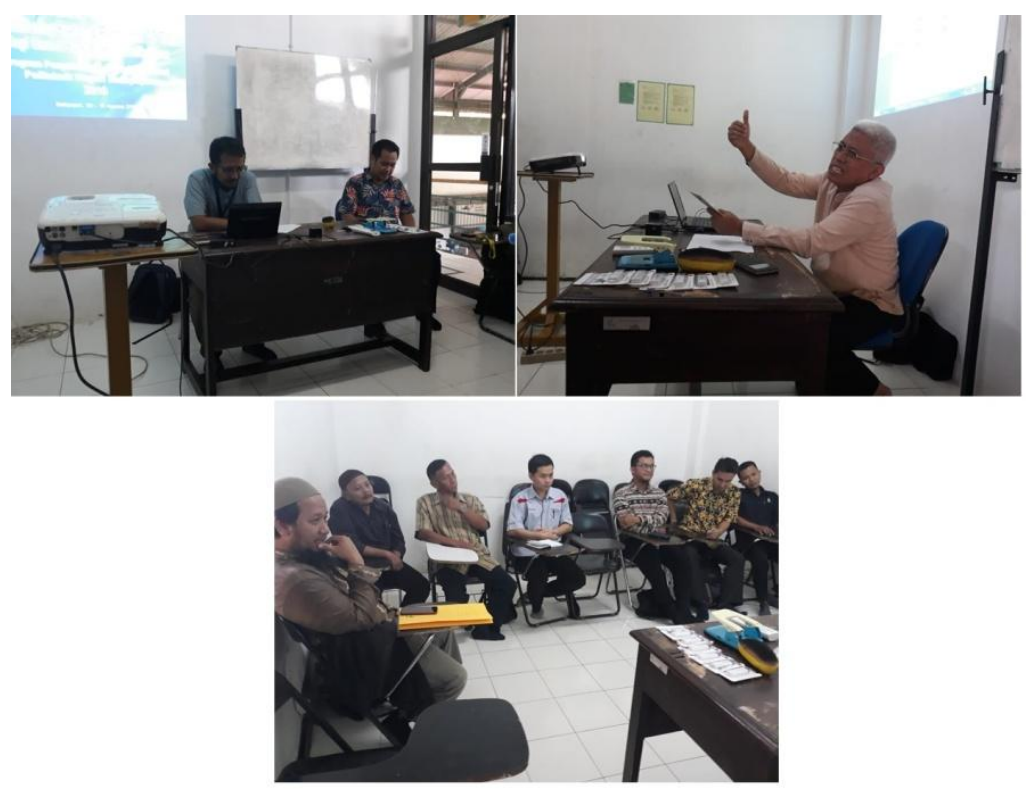

Gambar 3. Pelaksanaan teori kompetensi AC

Jumlah peserta pelatihan yang mengikuti pelatihan adalah sebanyak 7 orang yang merupakan perwakilan dari tiap-tiap sekolah SMK bidang keteknikan di Kota Balikpapan. Gambar 3 menunjukkan pelaksanaan teori, dan Gambar 4 menunjukkan pelaksanaan praktek kompetensi AC di Workshop Jurusan Teknik Mesin Poltekba. Materi teori meliputi konsep AC, sistem kerja, perhitungan dan desain AC, dan refrigerant. Komponen utama AC adalah evaporator, compressor, condenser, dan expansion valve [4]. Kegiatan praktek menitikberatkan pada perancangan, perakitan, dan pembuatan alat praktek AC. Salah satu hal penting selain teknis perangkat $\mathrm{AC}$, adalah tidak terjadinya kebocoran pada rangkaian $\mathrm{AC}$. Adanya gas refrigerant pada sistem AC sangat berbahaya bagi lingkungan apabila terjadi kebocoran [5].

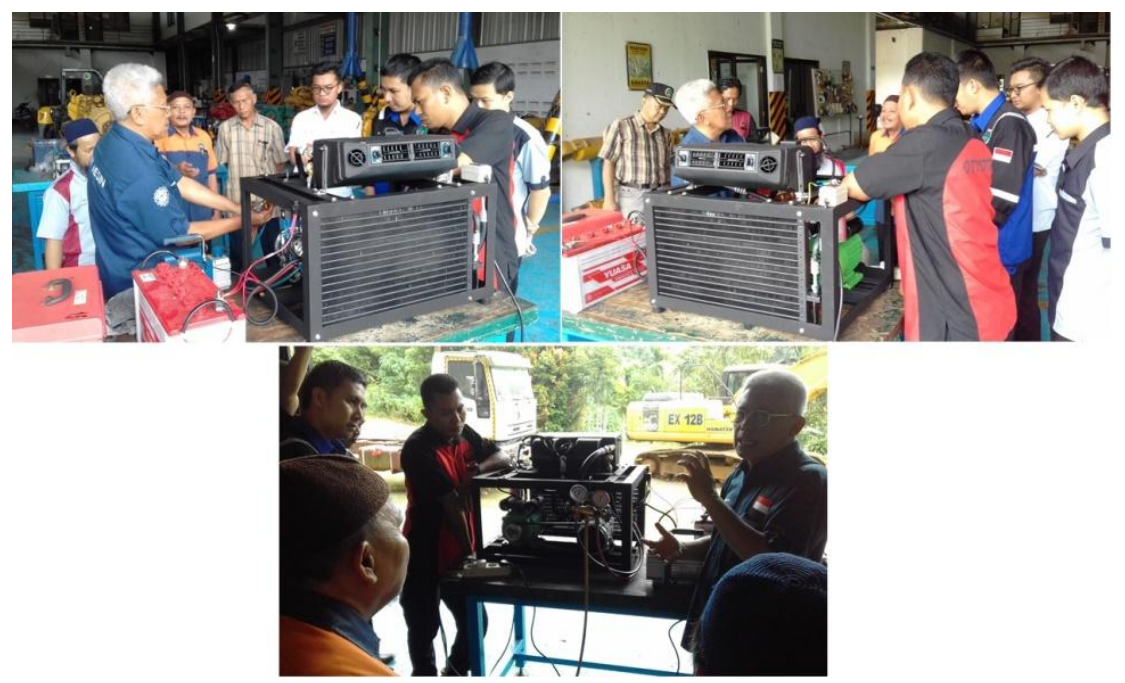

Gambar 4. Pelaksanaan praktek kompetensi AC

Penilaian keberhasilan pelatihan dilakukan menggunakan perangkat kuesioner yang dibagikan kepada peserta pelatihan. Jumlah inputan kuesioner sebanyak 7 responden sesuai dengan jumlah peserta. Penilaian pelaksanaan pelatihan meliputi efisiensi waktu, kualitas 
materi, kualitas narasumber, sarana prasarana teori/praktek, dan pelayanan panitia. Skala penilaian adalah 1 (tidak memuaskan), 2 (kurang memuaskan), 3 (cukup memuaskan), 4 (memuaskan), dan 5 (sangat memuaskan). Hasil penilaian pelaksanaan pelatihan ditunjukkan dalam Tabel 2. Berdasarkan hasil penilaian bahwa pelatihan telah diselenggarakan dengan baik. Terkait sarana ruang teori yang digunakan perlu ditingkatkan karena terdapat penilaian cukup sebanyak 2 responden.

Tabel 2 Hasil penilaian pelatihan

\begin{tabular}{c|l|c|c|c|c|c|c}
\hline \multirow{2}{*}{ No } & \multicolumn{1}{|c|}{ Variabel penilaian } & \multicolumn{4}{c|}{ Skala penilaian } & \multirow{2}{*}{ Total } \\
\cline { 3 - 6 } & & $\mathbf{1}$ & $\mathbf{2}$ & $\mathbf{3}$ & $\mathbf{4}$ & $\mathbf{5}$ & \\
\hline \hline 1. & Efisiensi waktu pelatihan & & & & 6 & 1 & 7 \\
2. & Kualitas materi pelatihan & & & & 4 & 3 & 7 \\
3. & Ruang teori pelatihan & & & 2 & 5 & & 7 \\
4. & Sarana prasarana praktek & & & & 5 & 2 & 7 \\
5. & Kualitas narasumber & & & & 2 & 5 & 7 \\
6. & Layanan panitia & & & & 4 & 3 & 7 \\
\hline
\end{tabular}

Akhir kegiatan pelatihan dilakukan pembagian sertifikat pelatihan kompetensi AC bagi peserta pelatihan. Selain itu juga dilakukan penyerahan alat praktek kepada salah satu perwakilan SMK. Gambar 5 menunjukkan pembagian sertifikat pelatihan dan penyerahan alat praktek kepada perwakilan peserta.

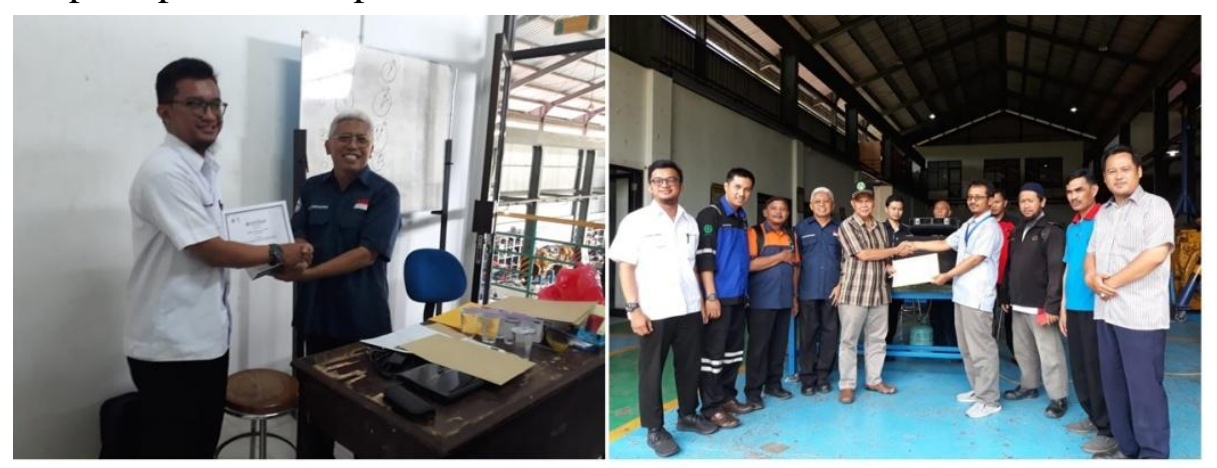

Gambar 5. Penyerahan sertifikat dan alat praktek AC

\section{Kesimpulan}

Kegiatan PKM yang diselenggarakan adalah pelatihan kompetensi AC bagi guru SMK bidang keteknikan Kota Balikpapan. Tujuan pelatihan adalah peningkatan kompetensi AC bagi pada guru, dan mampu membuat alat praktek AC secara mandiri.

Hasil penilaian pelaksanaan pelatihan menunjukkan bahwa pelatihan telah diselenggarakan dengan baik. Penilaian meliputi efisiensi waktu, kualitas materi, kualitas narasumber, sarana prasarana teori/praktek, dan pelayanan panitia. Terkait ruang teori pelatihan perlu ditingkatkan untuk penyelenggaraan pelatihan di lain waktu.

\section{Daftar Pustaka}

[1] Getachew, F., Nekatibeb, H., Workineh, S., Yitbarek, T., Gelaye, Y., Girma, T. (2017). Design and implementation of microcontroller based automated air conditioning control system for refrigerator truck. Science, Technology and Arts Research Journal, 4 (4), 131-137, DOI: http://dx.doi.org/10.4314/star.v4i4.20.

[2] Lee, M. Y. (2017). Design and cooling performances of an air conditioning system with two parallel refrigeration cycles for a special purpose vehicle. Applied Sciences, 190 (7), 1-12, doi:10.3390/app7020190. 
[3] Li, Z., Yu, J., Chen, E., Jing, Y. (2018). Off-design modeling and simulation of solar absorption-subcooled compression hybrid cooling system. Applied Sciences, 2612 (8), 1-18, doi:10.3390/app8122612.

[4] Li, K. Y., Luo, W. J., Huang, J. Z., Chan, Y.C., Pratikto, Faridah, D. (2017). Operational temperature effect on positioning accuracy of a single-axial moving carrier. Applied Sciences, 420 (7), 1-14, doi:10.3390/app7040420.

[5] Bellos, E., Tzivanidis, C. (2018). Investigation of the environmentally-friendly refrigerant R152a for air conditioning purposes. Applied Sciences, 119 (9), 1-21, doi:10.3390/app9010119. 
Syaeful Akbar, Wahyu Anhar, Basri Dahlan 